\title{
Interfaces
}

INTERFACES Image Texte Language

Crossing Borders: Appropriations and Collaborations

\section{On Appropriations}

\section{Véronique Plesch}

\section{(2) OpenEdition}

\section{Journals}

Electronic version

URL: http://journals.openedition.org/interfaces/308

DOI: 10.4000/interfaces.308

ISSN: 2647-6754

\section{Publisher:}

Université de Bourgogne, Université de Paris, College of the Holy Cross

\section{Printed version}

Date of publication: 1 January 2017

Number of pages: 7-38

ISSN: 1164-6225

\section{Electronic reference}

Véronique Plesch, "On Appropriations", Interfaces [Online], 38| 2017, Online since 13 June 2018, connection on 06 January 2021. URL: http://journals.openedition.org/interfaces/308 ; DOI: https:// doi.org/10.4000/interfaces.308

\section{(c) (i)}

Les contenus de la revue Interfaces sont mis à disposition selon les termes de la Licence Creative Commons Attribution 4.0 International. 


\title{
ON APPROPRIATIONS ${ }^{*}$
}

\author{
Véronique Plesch
}

Once one starts considering the notion of appropriation — or, more specifically, what Kathleen Ashley and I called "the cultural processes of appropriation"-it is easy to see it at work everywhere; as a matter of fact, Kathy and I concluded the introductory essay we wrote for the special issue of the Journal of Medieval and Early Modern Studies (JMES) we curated on this issue by stating that such processes are culture.

As a critical concept, "appropriation" has a history and its appearance in the scholarly vocabulary reflects important shifts in the ways in which culture and cultural production are envisioned and theorized. As we noted in our introduction, the term deserved an entry in Critical Terms for Art History and Robert Nelson's essay was meant to stand as "a deliberate repositioning and thus critique of the previous essay on influence" (Nelson and Shiff xix) that had appeared in Critical Terms for Literary Study, written by Louis Renza. In the art history volume, Nelson's entry followed that on originality, penned by his co-editor, Richard Shiff. Kathy and I noted that the "dialectical diptych" thus formed, fostered a dialogue between the two terms, one in which the concept of "appropriation" forces a reconsideration of "originality" (Ashley and Plesch 1). There is no need to review here how the concept of "influence" has eroded in recent decades (we are approaching the half century mark since the publication of Harold Bloom's Anxiety of Influence). Thinking in terms of influence means establishing the primacy of an urtext, an influential ground-breaking masterpiece. As Louis Renza argued in his essay on "Influence," it reifies the ideologies of "author" and "authority," while ignoring extraliterary influences and "culture-specific ideological circumstances" that impact the work of literature (193, 197). But intertextuality came to the rescue, allowing us to think in much more dynamic ways, with for instance in Roland Barthes' formulation that "a text is made of multiple writings, drawn from many cultures and entering into mutual relations of dialogue, parody, and contestation" (148).

Kathy and I discussed how the term of "appropriation" emphasizes the fundamentally active nature of what is not a one-time event but instead, a process, and how its etymology confirms this. From

1 *I wish to thank Maurice Géracht and his Interfaces colleagues for the invitation to deliver the plenary address at the 2016 conference and the opportunity to revisit the concept of appropriation. The students in my Visual Culture of Tattooing seminar greatly contributed to sharpening my thoughts on the question, in particular Lily Steig with her paper on Jews and Tattoos and Shauna Yuan with her research on Japanese tattooing. 
the Latin verb appropriare, made from the conjoining of the prefix ad and the adjective proprius-it means "to make one's own" (Nelson 117). Two very important issues are at stake and are apparent in the word's etymology: power and identity. To appropriate is to gain power over something as it is made one's own. And this is in part why the term carried negative associations when it was first used in cultural studies - and continues to do so, as the notion moved beyond the confines of academic discourse into that of political correctness. Nowadays, in common speech, seldom does the term "cultural appropriation" convey positive connotations. Used in this sense, it functions within a binary and one-directional scheme, one in which a dominant culture appropriates and a weaker culture has no control over its representations or products that are appropriated. Critics even saw a hegemonistic dimension in the theory itself, silencing, or better, as Benita Parry put it, "disarticulating the native" (34). Parry went as far as declaring that Gayatri Spivak, in her postcolonial view of cultural appropriation, "gives no speaking part to the colonized" (Parry 35). In this backlash in post-colonial theory, scholars strove to understand the ways in which "natives," "subalterns," "others" may in fact be agents rather than powerless victims, capable of resisting or subverting the imposed colonial agenda even though they may appear to be adopting the tools of the dominant culture. In our essay, we mentioned some important concepts that were generated at that point in the critical discourse, such as Homi Bhabha's "colonial mimicry," which is, in Bhabha's terms, "at once resemblance and menace" (86) and Mary Louise Pratt's "contact zone," where colonial encounters take place and where the active and creative process that ethnographers call "transculturation" occurs.

Pratt's "contact zone" introduced a spatial dimension to our understanding of these processes, a characteristic that appears, albeit in different formulations, in other writers. Bhabha, for instance, considering the contact zone's liminal nature, described it as an "interstitial passage between fixed identifications" that "opens up the possibility of a cultural hybridity that entertains difference without an assumed or imposed hierarchy" (4). For Gloria Anzaldúa, it is the "Borderlands" or frontera: not only the actual geographic space between the United States and Mexico where she grew up as a Chicana, but also, metaphorically, a site of multiple languages, cultures, and gender identities. Just as in the title of this conference and issue of Interfaces, the matter is one of "Crossing Borders," or rather of considering a space in which "borders"-frontières and fronteras-become the site for cultural productions. 


\section{Iconographic innovation as Appropriation in a Contact Zone}

Perhaps because of heredity and biography — my ancestors and I have crossed many bordersthe idea of movement across geographic boundaries and of a contact zone as the site for creative ideas has been a recurrent theme in my scholarship, long before Kathy and I edited the issue on appropriation. Very early on, I was fascinated by the possibility of envisioning the Alps as an area possessing a distinct artistic culture. I was taking a cue from the work of Enrico Castelnuovo, who back in the 1960s had called for considering the Alps as a "possible locus of autonomous cultural elaboration, and not just as a simple place of transit"" ("Les Alpes, carrefour" 13). My attention had been drawn to the question serendipitously, as I was studying Enguerrand Quarton's Coronation of the Virgin (Fig. 1) and collected early instances of the iconography of the Coronation of the Virgin by the Trinity, from the moment it appears at the very end of the $14^{\text {th }}$ century and up to Quarton's altarpiece in the middle of the $15^{\text {th }}$ century (Fig. 2). ${ }^{3}$ The results of my survey, a catalogue of 26 renditions of the theme, revealed the role played by the Alpine zone in the creation of a new iconography in which it is not Christ alone who crowns Mary but the entire Trinity: 73 percent of the works (a total of 19) were created in alpine or subalpine areas (Plesch, "Innovazione iconografica"). Interestingly, what is at stake in this instance of iconographic innovation, are processes involving appropriation as the new theme is the result of an ars combinatoria in which disparate elements were brought together. The earlier iconography of the Virgin crowned by Christ alone (Fig. 3) merges with a certain type of depiction of the Holy Trinity, in which God the Father and Christ share a throne (Fig. 4) and in so doing enhances Mary's glorification. Perhaps not so surprising is the fact that this additive modus operandi was already at work in the creation of the two original iconographies. Because there is no single scriptural source for it, the Virgin crowned by Christ is the result of exegetical bricolage, in which several biblical texts play a role (the Song of Songs, Psalms 44 and 109, along with references to several Old Testament couples; Thérel, Verdier), while the Trinity is one of the most complicated theological themes to be given visual form, a true "iconographic conundrum" (Plesch, "Enguerrand Quarton's Coronation" 194) in which too many contradictory notions have to be given form at once: three hypostases, who are different and yet consubstantial and coeternal, with complex relationships woven among them-generation from Father

Otherwise noted, all translations are mine.

3 This research was first conducted for a mémoire de licence ès Lettres at the Université de Genève, Switzerland ("Le Couronnement de la Vierge d'Enguerrand Quarton: Théologie et histoire des mentalités d'une iconographie, $\mathrm{XIV}-\mathrm{XV}$ - $\mathrm{XVI} \mathrm{I}^{\mathrm{e}}$ siècles," under the direction of Florens Deuchler, defended in 1984); some of the results were published in Plesch, "Le Couronnement," "Innovazione iconografica," and "Enguerrand Quarton's Coronation." 


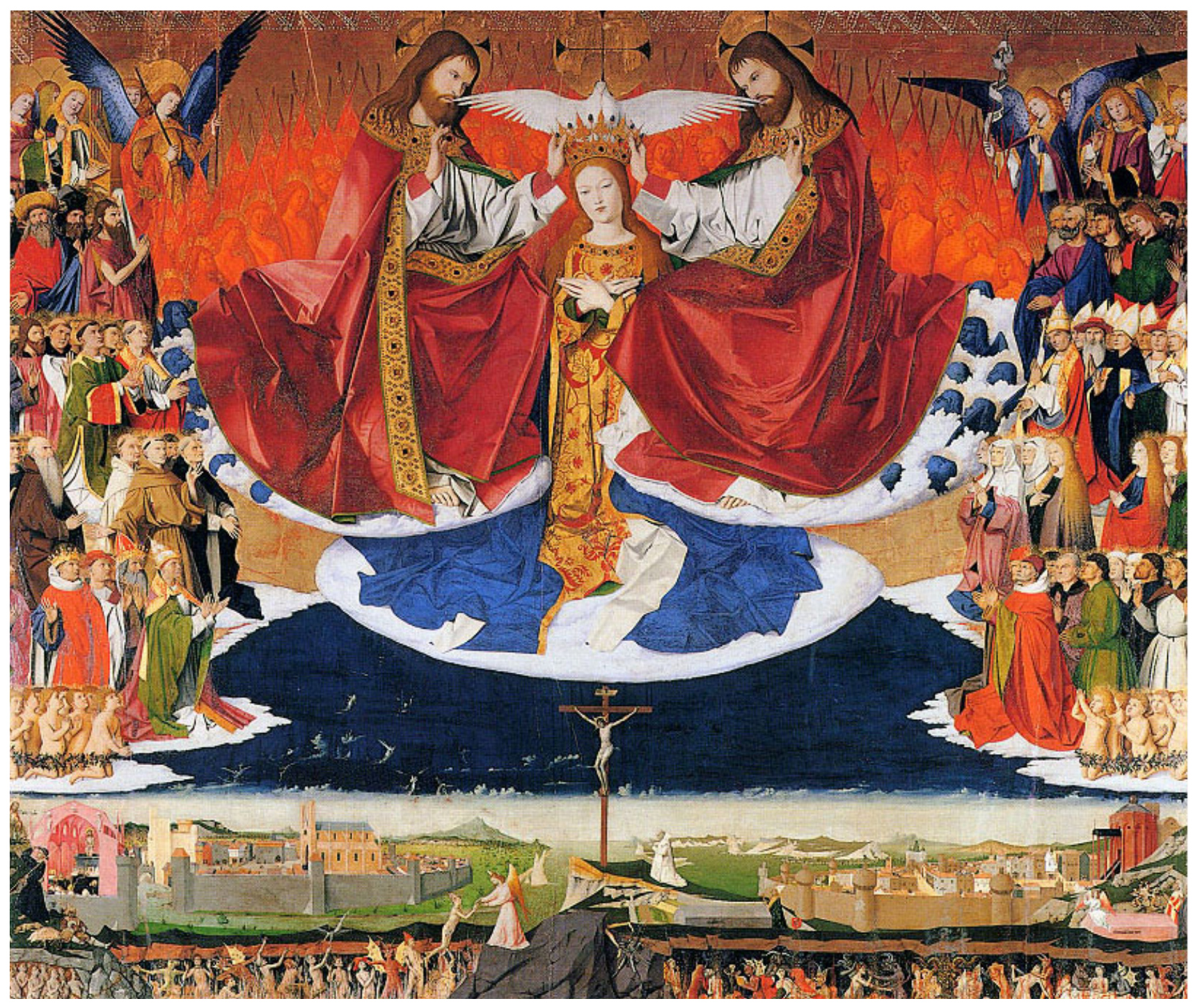

Fig. 1. Enguerrand Quarton, Coronation of the Virgin, 1353-54. Tempera on panel. Musée de l'Hospice, Villeneuve-lès-Avignon. 


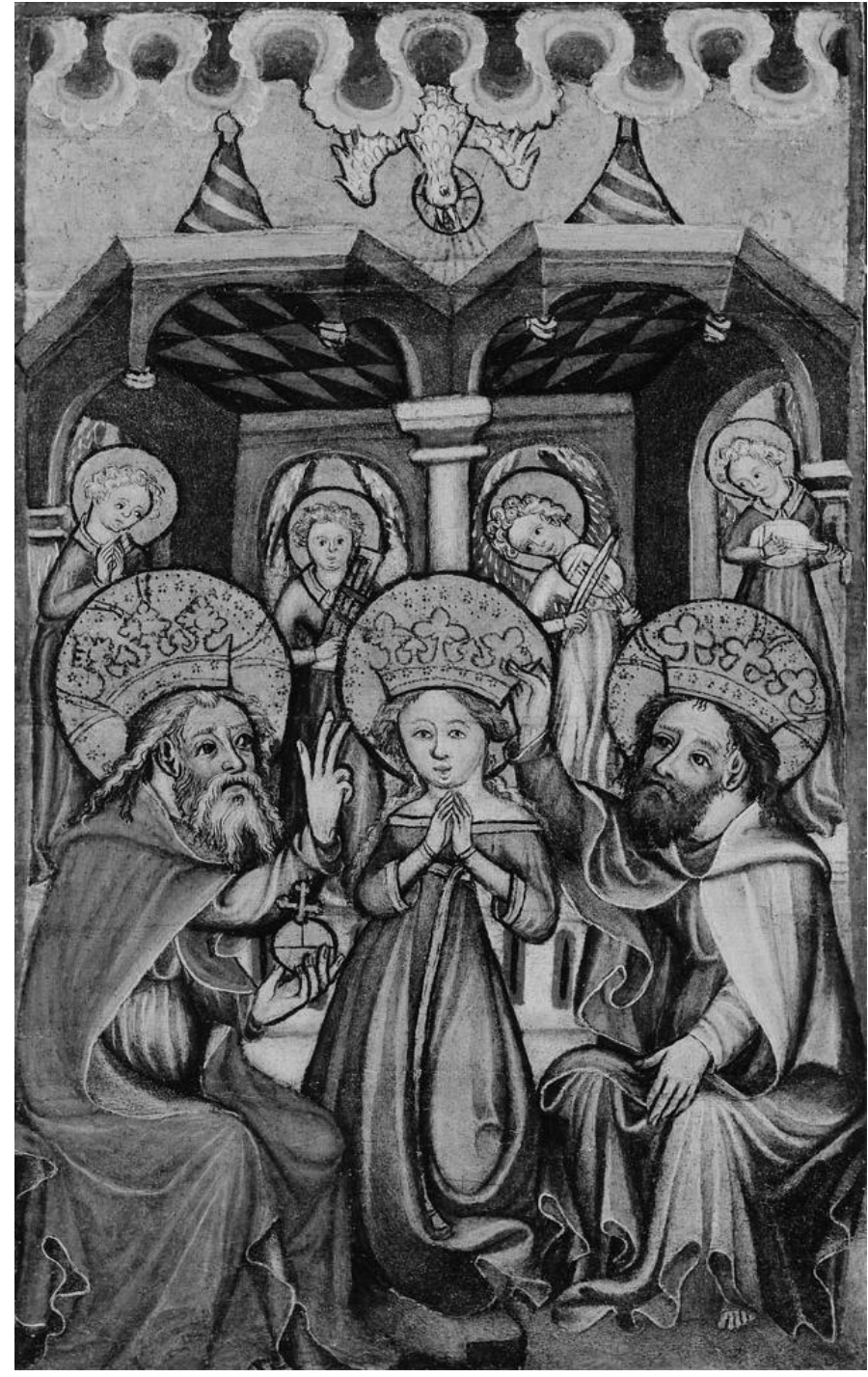

Fig. 2. An early example of the iconography of the Virgin Crowned by the Trinity: anonymous Tyrolean artist, first quarter of the $15^{\text {th }}$ century. Tempera and oil on panel, Museum of Fine Arts, Boston. 


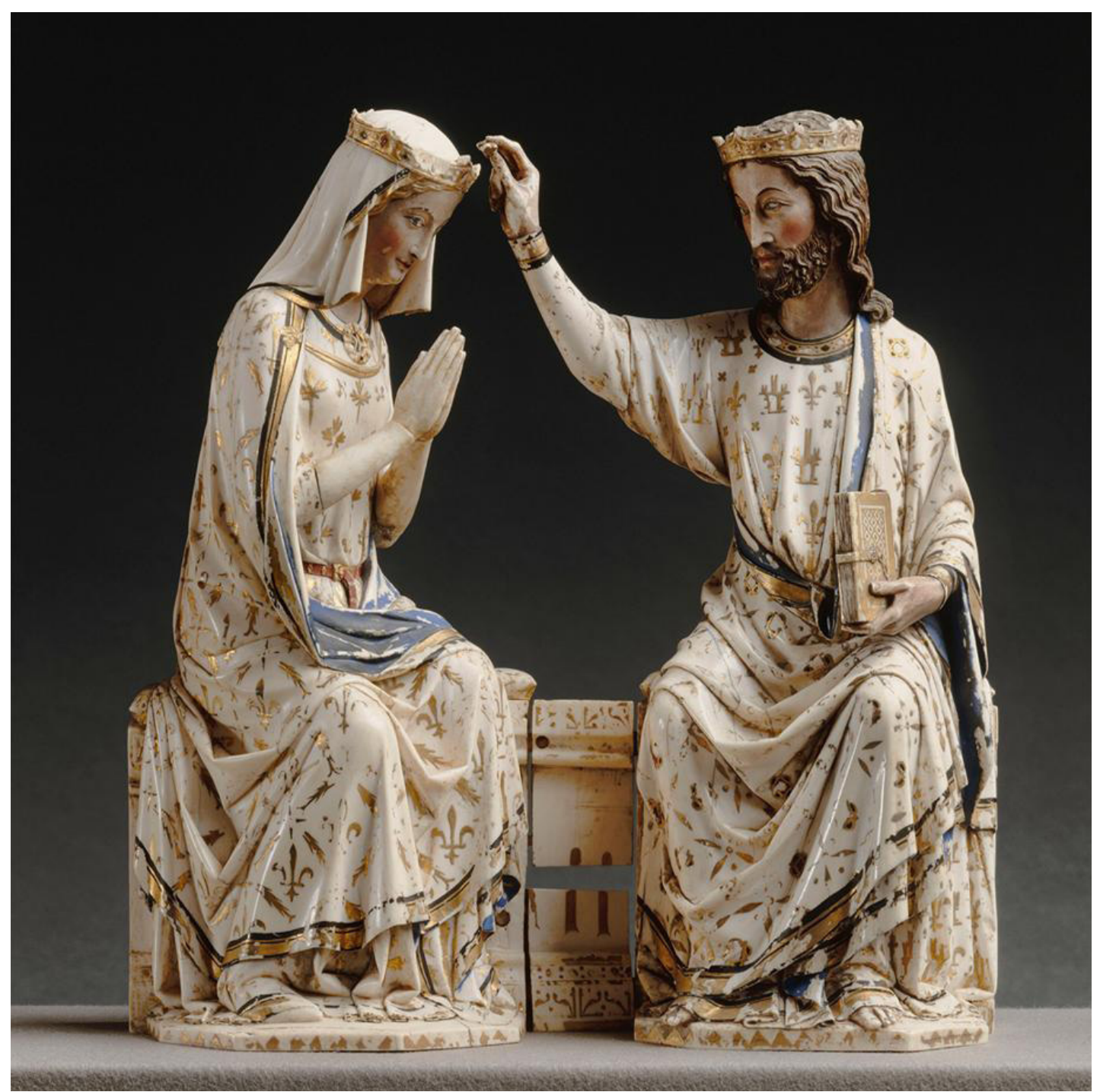

Fig. 3. Coronation of the Virgin. Paris, $13^{\text {th }}$ century. Polychrome ivory. Musée du Louvre, Paris. 


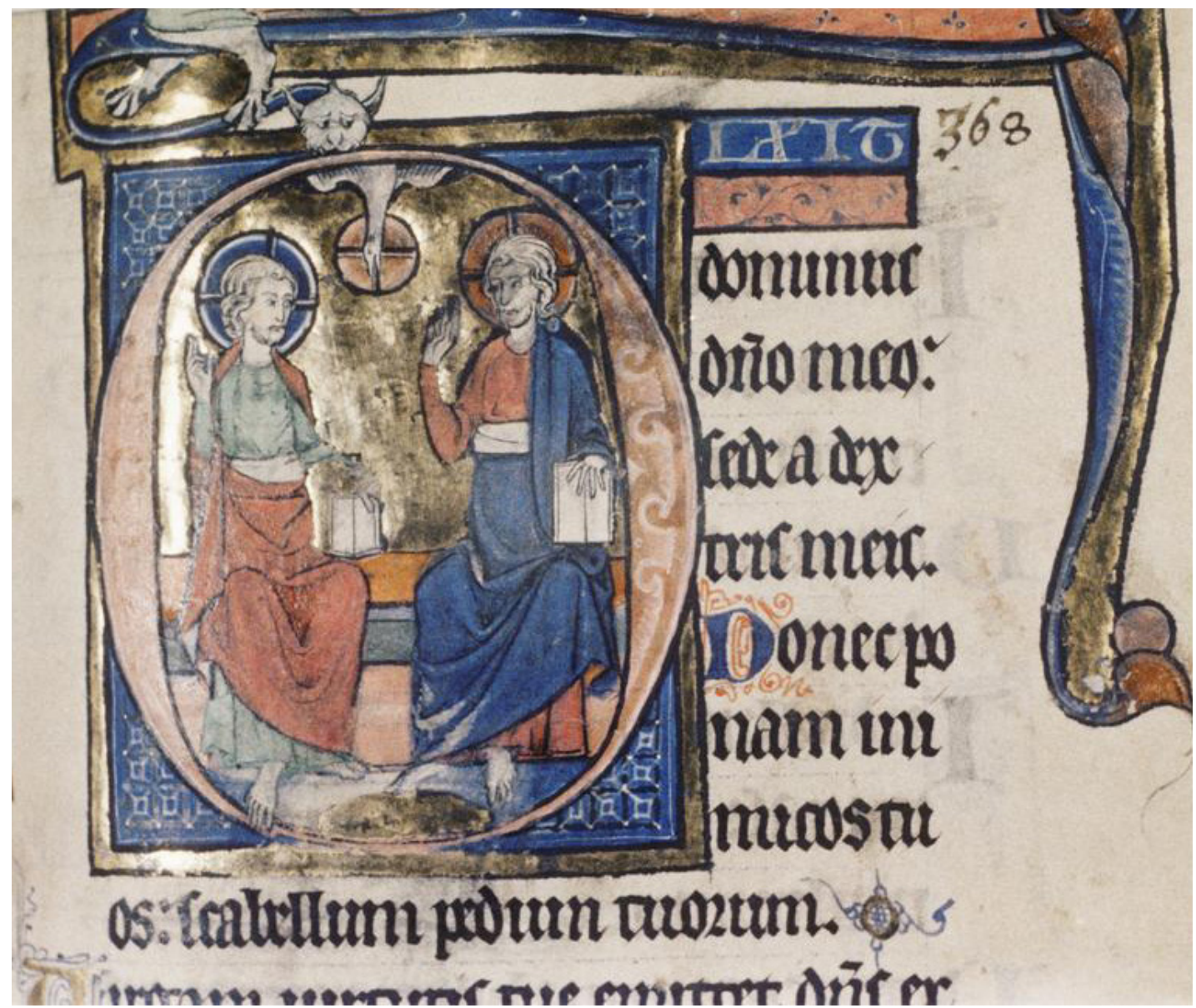

Fig. 4. Example of the type of Trinity that played a role in the creation of the iconography of the Virgin Crowned by the Trinity: illumination from a French Psalter, $3^{\text {rd }}$ quarter of the 13 th century. MS. Douce 50, fol. 368r. Bodleian Library, Oxford. 
to Son, filiation from Son to Father, and procession for the Holy Spirit (this last one being in itself a matter of open theological debate). And if that were not enough, artists are faced with yet another dilemma: whether to represent Christ according to his divine or human nature, or better still, how to allude to both?

This particular instance of iconographic innovation reveals the dynamic and creative role played by an area that is thus more than just a border separating the cultural worlds of Northern Europe and Italy. I should note that this geographic distinction carries profound implications in terms of periodization given the traditional discourse of the Renaissance as an Italian (Florentine) creation. Not just a peripheral zone, ${ }^{4}$ the Alps possess a distinct identity, one that has been recognized by geographers and historians, and that manifests itself on many levels: physically, economically, historically, and culturally (Castelnuovo, "Les Alpes, Carrefour" 14). To the many metaphors that scholars have used in order to grasp this specificity (hinge, suture, ellipsis, cushion, etc.; see Plesch, "L'Art du XV siècle" 71), one could add the "interstitial passage" that Bhabha saw in contact zones. Bhabha's phrase is particularly relevant in the case of the Alps in the early modern period, before modern borders were established on the spartiaqua, the mountains' crest. At that time, the Duchy of Savoy controlled the Western Alps, and this is why the Dukes were nicknamed by the king of France Francis I, the "porters of the Alps." Indeed, the Alps functioned as an area of communication rather than a barrier, the mountains uniting rather than separating, a phenomenon that continues to this day, suffice to think how during the summer, the high pastures gather people and cattle from both sides of the range. ${ }^{6}$ And the fact that these new formulations are the result of an ars combinatoria is surprisingly similar to Bhabha's "cultural hybridity," or to what in certain situations is referred to as métissage or creolization. The late Enrico Castelnuovo would have agreed with this remark: in an essay published in 2008, as he revisited his earlier reflections on the Alps as an artistic zone, he went as far as envisioning it as the place for "métissages culturels" ("Les Alpes au début du XVe siècle" 20).

4 For the discussion of the concept of periphery, see Castelnuovo and Ginzburg.

5 Qtd. in Guichonnet 290; see also Castelnuovo, "Les Alpes au début du XV e siècle" 22-23, for the concept of Paßstaat, coined by Friedrich Ratzel to refer to political entities controlling roads and mountain passes, which was popular for a while in early $20^{\text {th }}$-century historiography.

6 Jean-François Bergier in Guichonnet 221, called the $14^{\text {th }}$ and $15^{\text {th }}$ centuries "Les Alpes ouvertes." 


\section{Diachronic and Synchronic Approaches to Appropriation}

To go back to the JMEMS introductory essay, and to the many ways in which the colonized can resist through appropriation, what it boils down to, is that "appropriation" is a two-way process. Kathy and I remarked that all the essays in the special issue avoided "the reductive model whereby every act of appropriation must be one of imposed power" (Ashley and Plesch 6). Instead, the authors explored instances of creative responses and put the emphasis on the process, and not just on the content or the product. Focusing on the processes allows scholars to observe the fluidity of a chain of appropriations that extends over long periods of time. Kathy and I noted that "[by] taking a diachronic approach, we can perceive the processes by which a symbol accrues power or-in Bourdieu's term, cultural capital — and is ripe for appropriation for a new purpose (Ashley and Plesch 8; Bourdieu).

Here too, I will provide an example drawn from my own scholarship. The focus on the process rather than the finished product is central to understanding the ways in which Giovanni Canavesio, an artist and priest from Pinerolo in Piedmont, who spent most of his career in Liguria and the Pays niçois, appropriated Northern engravings and adapted them to the format of a fresco cycle and to his cultural environment. ${ }^{7}$ As I studied the pictorial cycle on the Passion of Christ that Canavesio completed in 1492 for the pilgrimage sanctuary of Notre-Dame des Fontaines outside La Brigue (some 80 kilometers north-east of Nice), I considered his rather extensive use of engravings as a source for details, for figures, and even, in some cases, for entire compositions. Canavesio used at least two sets of prints: the Large Passion, engraved by the German Israhel van Meckenem around 1480, and, to a lesser degree, an anonymous series, considered to be Lower Rhenish or Netherlandish and dated circa 1485-1500 (because of its use at La Brigue the terminus ante quem for this latter should be brought before 1492). Close study revealed that Canavesio used these source materials with discrimination as is shown by the range of his borrowings as well as by the modifications he introduced, adapting them to the sociocultural realities of his time and geographic area (for instance altering costumes and gestures), while also reworking positions according to his artistic temperament. In order to successfully enhance the narrative coherence of the ensemble, he also introduced recurring figures who appear elsewhere in the cycle. Finally, and along the same lines of medium specificity, he revised compositions according to the requirements of fresco painting.

7 For details on what follows, see Plesch, Painter and Priest, in particular chapter 4, "Imitatio: Pictorial Sources of the Passion Cycle at Notre-Dame des Fontaines" 91-151. 
At first glance, Canavesio's Christ's Crowning with Thorns (Fig. 5) appears very close to Meckenem's print (Fig. 6) and yet, it is not a slavish copy. Because wall painting does not allow the minute detailing one finds in engraving, Canavesio reduced the cast of characters (here, for instance, he eliminated the secondary scenes that the engraver had included in the background) and simplified the depiction. The comparative size of the figures to the overall size of the panel was also adapted: Canavesio's figures are larger than in the prints, allowing for successful viewing from a distance. The format was also revised: the prints were vertically oriented, while the paintings are horizontally oriented, and as a result the viewpoint is different: Canavesio's figures are seen from the same level as the beholder, and not from above, as in the print. Furthermore, and within each scene, Canavesio stressed the horizontal component, organizing the figures close to the foreground. As much as possible, the protagonists' placement emphasizes a left-right thrust in the reading and contributes to propel the viewer's eye from panel to panel. All these transformations and in particular the emphasis on the continuity between the panels can be explained by the medium, by the fact that while prints exist on individual sheets, monumental paintings are placed side by side like a comic strip, forming a succession of moments to be perceived as belonging to a larger ensemble. Furthermore, prints are experienced intimately and privately and wall painting is a "public" art, but by changing the format and the viewpoint, by bringing the protagonists closer to the picture plane and therefore to the viewer, Canavesio diminished the distance between the representation and the spectator, regaining in part the individual and immediate experience one has with prints.

Fig. 5. Giovanni Canavesio, Crowning with Thorns, 1492. Fresco. Notre Dame des Fontaines, La Brigue. Photo: author.

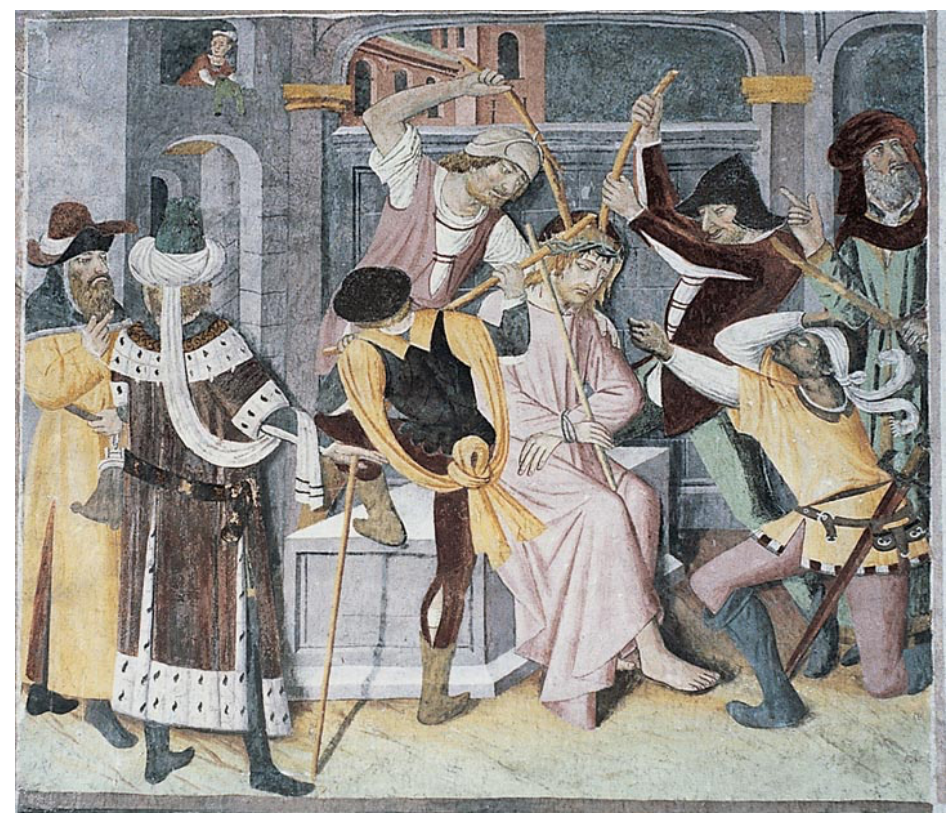




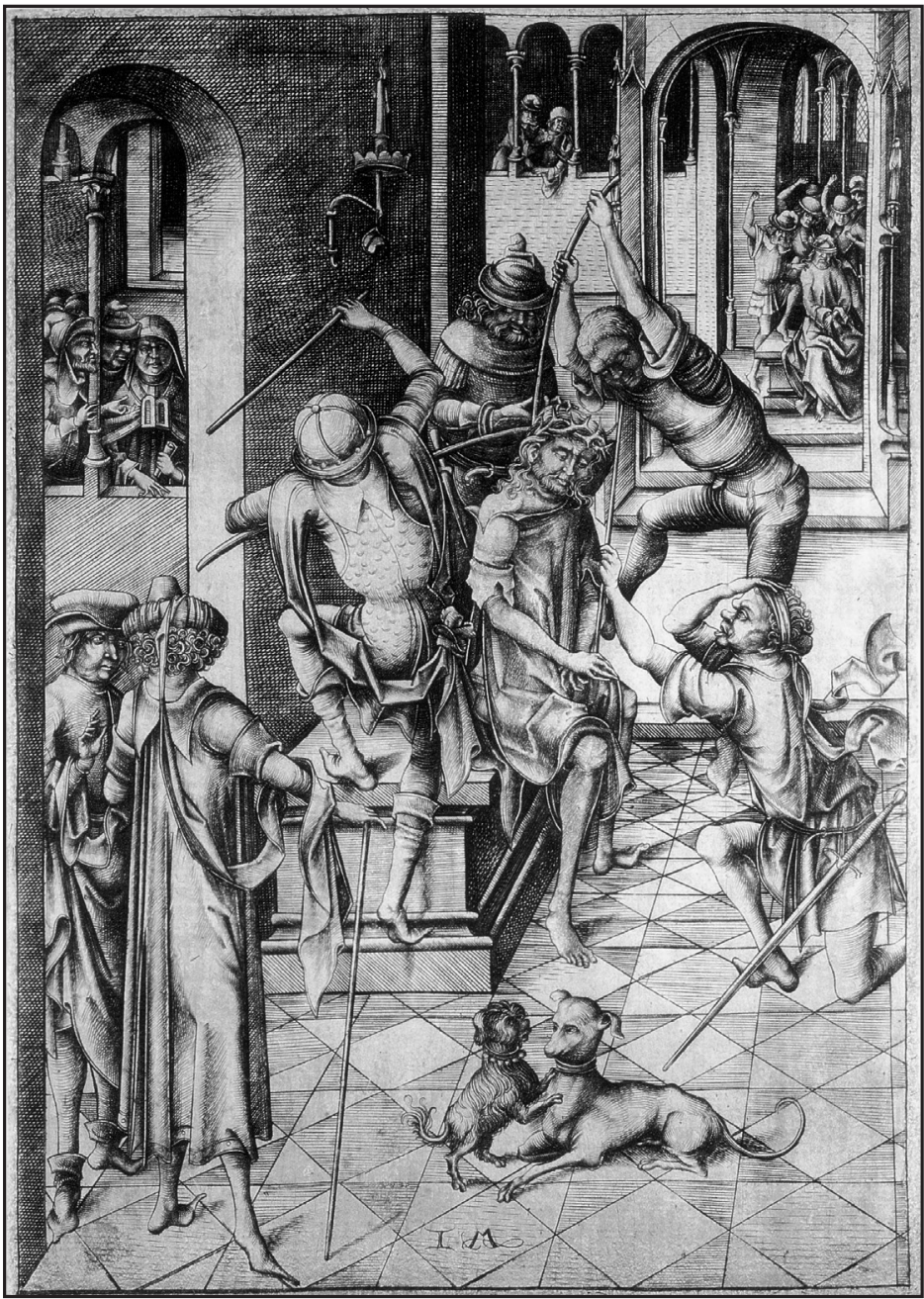

Fig. 6. Israhel van Meckenem, Israhel van Meckenem, Crowning with thorns, from the Large Passion series, c. 1480. Engraving. National Gallery of Art, Washington, DC.
A couple of other interesting changes are worth mentioning. In Israhel's engraving, the moor who kneels in front of Christ on the right of the composition, hands Christ a reed, while in the fresco Christ already holds the ironic scepter, and so the moor, whose position closely repeats the print, extends his arm in an insulting gesture called in French "la figue" and in Italian "mano fica." Such a change can be understood in terms of "cultural adaptation," inserting an element of nonverbal communication that frequently appears in other contemporary representations from Canavesio's artistic area. Throughout the cycle, other modifications can be considered attempts to integrate further the borrowings into Canavesio's ambient culture. These can be seen in the costumes, which very seldom are literally copied from the prints. Here for instance, it is the case with the moor's costume: only the headband and the sword were retained. 
Canavesio's appropriation of motifs and compositions from graphic sources can be traced within his own oeuvre and in particular his Passion cycles. By conducting careful comparisons, I was able to ascertain that in his first Passion cycle, which he completed in 1482 (San Bernardo in the Ligurian town of Pigna), Canavesio did not know or choose to use the prints. He had access to Israhel's Large Passion before 1490, when at work in San Dalmazzo in the Ligurian town of Pornassio (because of the cycle's fragmentary state, it is not possible to ascertain whether or not he used the anonymous Passion series). Canavesio still had direct access to Israhel's prints when working at Notre-Dame, as is proved by the presence of borrowed motifs distinct from what is to be found at San Dalmazzo. Finally, when he worked at the chapel of the White Penitents in the French town of Peillon, Canavesio did not introduce new motifs from prints but rather referred to his own cartoons, especially those from Notre-Dame (thus confirming that Peillon was painted after La Brigue). Here as well, the innovation never occurred ex nihilo and was instead the gradual reworking of compositional schemes inherited from the local tradition, combined with new borrowings from works of graphic art. It is remarkable that Meckenem himself was both aware of the use of prints by artists and took advantage of this potential but also is known as an artist who "pirated" other artists' works - a modus operandi that will remain challenging for scholars as long as originality is the most desirable quality and crucial factor in determining an artist's importance.

Appropriation does not enfold solely in a diachronic manner as just observed in the case of Canavesio's appropriation of prints (and reworking of his own compositions), but it also possesses a synchronic dimension: we should consider the fate of what is appropriated, how it changes as it is submitted to the processes of appropriation, and how much is retained of its original meaning and/ or function. In our introductory essay to the JMEMS issue, we proposed to envision the synchronic spectrum of appropriation, with at one end a situation in which what is appropriated fully retains its original meaning or function while at the other end it looses it completely - although in reality the extreme edges of the spectrum are abstractions, never fully reached. So, for instance, a liturgical object might change hands but will continue to be used in exactly the same manner while, at the other end of the spectrum, we might take the example with which Claire Sponsler started her paper: the Coca-Cola bottle in The Gods Must Be Crazy (Ashley and Plesch 10, Sponsler 17). This spectrum is useful as a means to gage what happens to what is appropriated and we noted how Claude Lévi-Strauss's notion of bricolage comes in handy in observing the processes at work.

8 Some four-fifths of his works are copies after other artists (Shestack text before no. 154); remarkable is the fact that some of the prints from the anonymous Netherlandish series that Canavesio used are known in a later state bearing retouches by Meckenem, among others his monogram. For a review of two recent exhibitions on Meckenem's prints, see Koreny. 
My own essay in the special issue focused on the material I have been studying for quite a few years now: the corpus of about 150 graffiti that appear on the $15^{\text {th }}$-century frescoes of the small oratory of San Sebastiano in the Northern Italian town of Arborio (Figs. 7 and 8; Plesch, "Memory"). There, the processes of appropriation operate in more than one way and at more than one level. We have a series of appropriations, each involving a focused spatial choice. A building — the chapel—was appropriated, and more specifically, its walls; the inscriptions appear on specific frescoes: it is clear that the effigies of saints were selected over the narrative scenes. The choice of the building was itself very meaningful: placed at the edge of town and thus preferred to the centrally located parish church, the chapel and its graffiti acted, I suggested, as a symbolic protective wall. (Remarkably, the buildings in which we find graffiti that like Arborio's allude to communal events, are always located at the border of settlements). The placement of the inscriptions on the iconic depictions of saints, indeed the appropriation of the pictorial surface, expressed the community's desire to establish a contact with the holy figures in a way that is informed by devotional practices - or, I could say, through the appropriation of such practices. Because of its syntactic, thematic, and topographic homogeneity, Arborio's corpus of graffiti reveals significant parallels with behaviors of a ritual nature, in which features such as formality, fixity, and repetition have been identified by scholars as central to what Catherine Bell calls "ritualization." By recording on the oratory's walls communal events, most of which, I should note, are of a negative and traumatic nature, the oft-threatened community was indeed appropriating history, and affirming that these events, even if endangering the town's survival, were constitutive of its identity, and that it had a long and documented history. This recording also introduced an active element in what could have been a rather passive experience-but this too is a function of ritual; Clyde Kluckhon, rather pithily declared that ritual gives "people something to $d o$ "10! Ultimately the fact that this practice lasted for at least four centuries speaks to its symbolic efficacy; as well as to the fact that the authorities at the very least tolerated it. And this, by the way, goes against our contemporary perception of graffiti-and especially of graffiti on paintings - as gratuitous and reprehensible acts of vandalism. As an instance of appropriation, Arborio's graffiti can be located midway on the spectrum Kathy and I sketched in our introductory essay: by writing on the saints, the town appropriated frescoes as support for inscription but the devotional purpose of such depictions remained. The intermingling of the secular with the religious is not unusual: we should keep in mind the myriad examples of medieval and early modern devotional and ritual behaviors that were endowed with a social and communal dimension.

$9 \quad$ For ritualization as an interpretive tool, see Bell 267.

10 Kluckhohn 71. Emphasis his. Similarly, Catherine Bell sees ritualization as "fundamentally a way of doing things to trigger the perception that these practices are distinct and the associations that they engender are special." See Bell 220. 


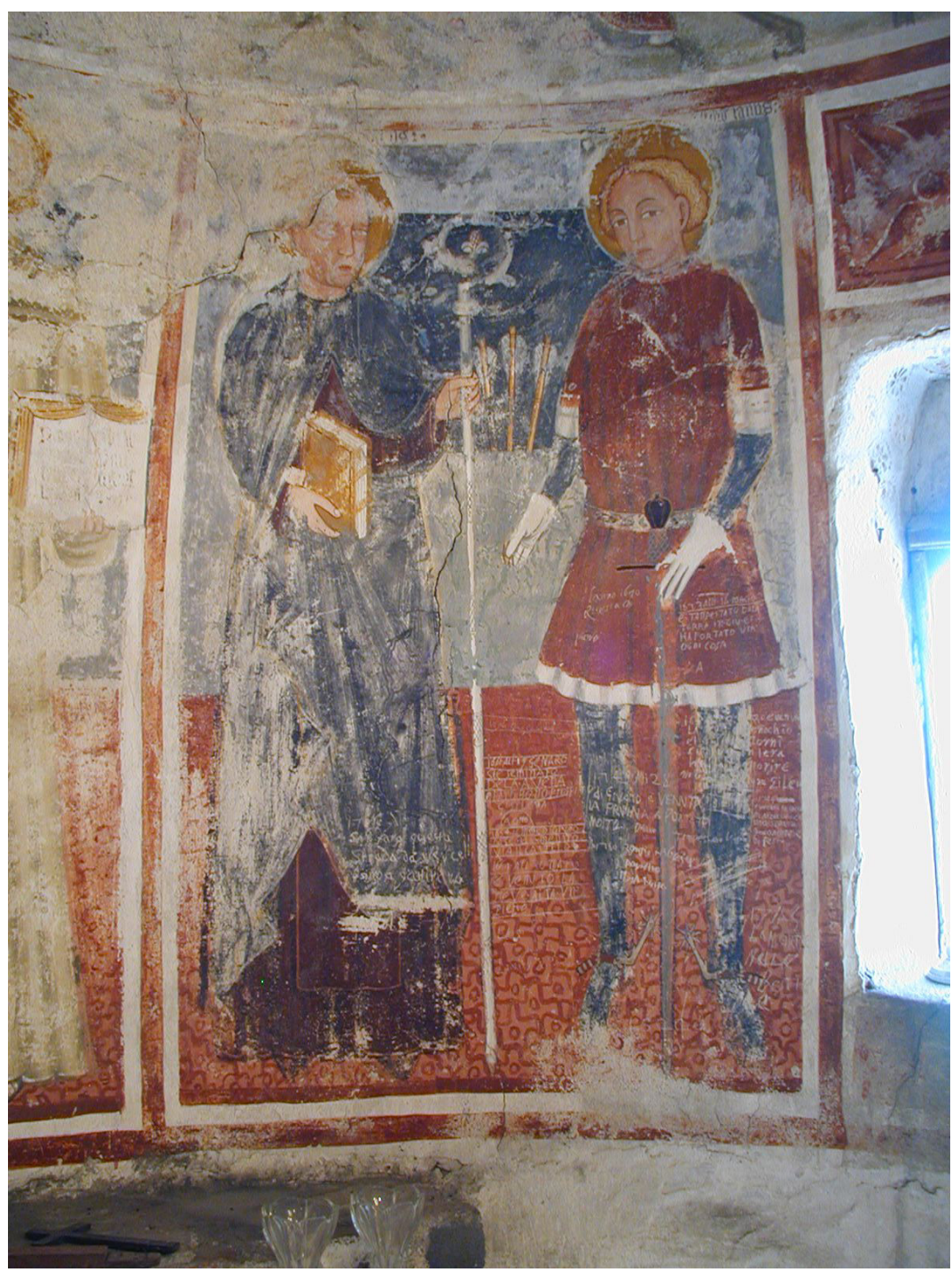

Fig. 7. Saint Fabian and Saint Sebastian. Fresco. Oratorio di San Sebastiano, Arborio. Photo: author. 


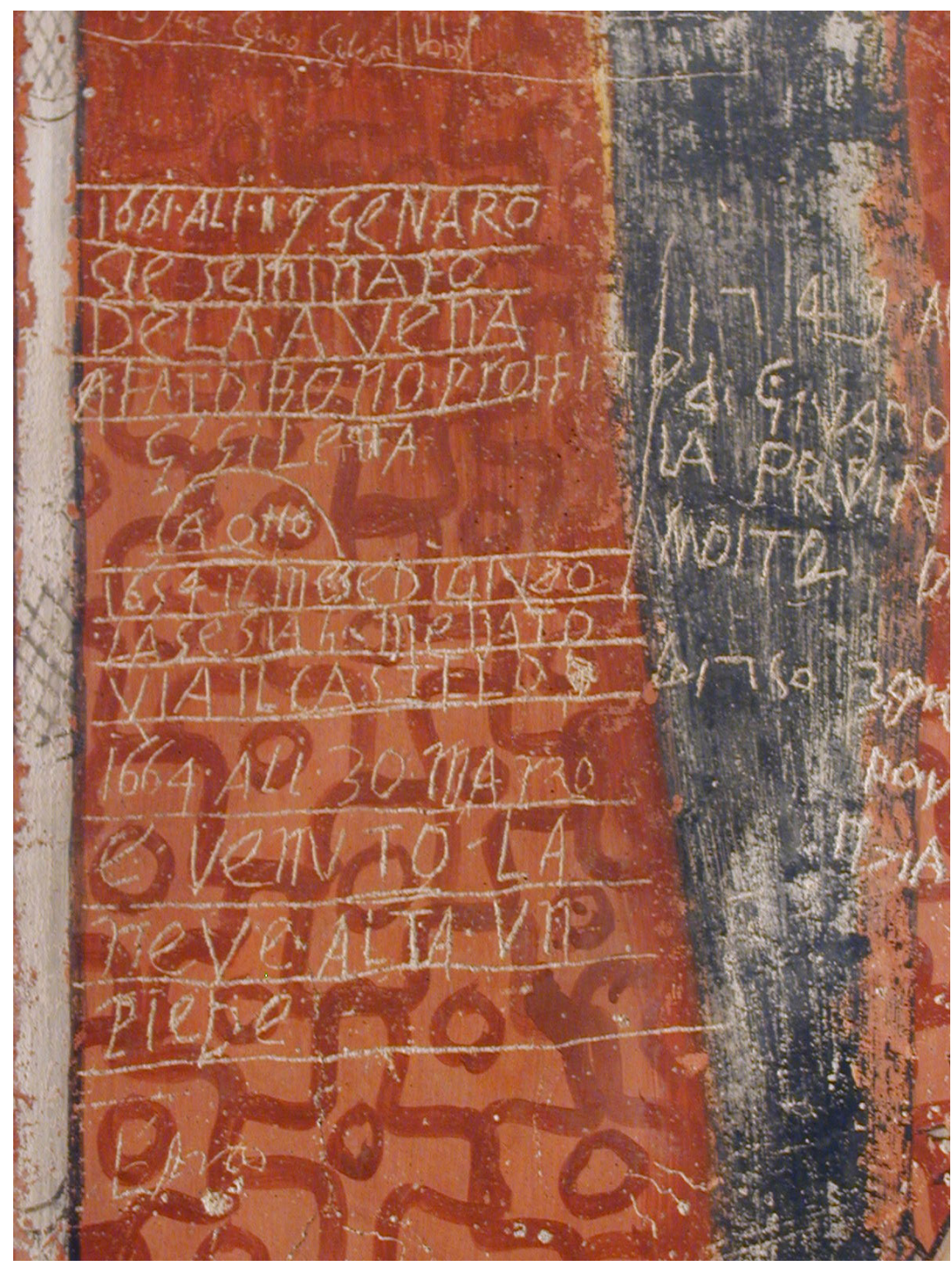

Fig. 8. Oratorio di San

Sebastiano, Arborio, detail of graffiti on St. Sebastian: "1661 ali 17 genaro si e seminato dela avena a fato bono pro to G. Giletta" ("1661 on 17 January we sowed oats and made good pro t, G. Giletta”); “1654 [a otto] il mese di giuno la sesia a menato via il castello" ("1654 on 8 June the Sesia River took away the castle"); "1664 ali 30 marzo è venuto la neve alta un piede" ("1664 on 30 March a foot of snow fell”). Photo: author. 


\section{Tattooing: the Skin as Border}

This is a very brief sketch of some of the ideas I developed in order to grasp what is going on at Arborio. In fact, and over the course of eight published papers, with a ninth one on its way, and far too many lectures and conference papers to count, I have considered this case study from a whole range of perspectives, deploying what I call my "theoretical opportunism" (Plesch, "Beyond Art History" 56) for I use whatever allows me to "think outside of the box" and gain a fresh perspective on this puzzling practice, or, to use a rather felicitous metaphor given our conference subject, what Mieke Bal has referred to as "travelling concepts." For instance, in my JMEMS article I explored parallels with tattooing. This was of course motivated by the simple fact that Arborio's inscriptions appear on the bodies of the saints-or on the pictorial field, right next to their bodies. Having noted an element of violence-after all, the graffiti deface the images and if the practice were to be carried on for too long, it would lead to the pictures' obliteration-I addressed the ambivalence in the relationship established with the holy figures, at once devotional reverence and coercive aggression. This ambivalence is exactly what characterizes the history of tattooing in the West; in that sense it is quite different from traditional societies, where the meaning and function of tattooing remains stable, while in the Western world, in addition to being discontinuous, we see a constant fluctuation among negative meanings - as in penal tattoos or the marking of slaves - to positive ones with, for instance $18^{\text {th }}$-century aristocrats acquiring ink. ${ }^{11}$ Today, we are certainly back at a high point, several decades into what Arnold Rubin has termed a tattoo Renaissance: according to a 2015 Harris Poll, "[a]bout three in ten Americans (29 percent) have at least one tattoo." Among Millennials, the number grows to 47 percent and "among those with any tattoos, seven in ten (69 percent) have two or more" (The Harris Poll). Tattooing is so much part of our contemporary landscape, that already in 2003 a survey revealed that " 88 percent of those interviewed said they know at least one person who has a tattoo" (Kang and Jones 42). In the past half century or so, tattooing has migrated from low to high, from being associated with criminals, circus performers, sailors, bikers, and gang members, to appearing in couture advertisement. ${ }^{12}$

As tattooing in the West fluctuated between low and high points, at times, the practice was appropriated and retained some of its original meaning, for instance when early Christians adopted

11 The articles gathered in Caplan offer an excellent survey of the history and practice of tattoo.

12 I am referring to several Valentino campaigns (starting in the spring of 2013), in which the heavily tattooed arms of photographer Terry Richardson appeared next to the featured luxury leather goods. 
the Roman custom of marking slaves as an expression of their voluntary servitude to Christ. ${ }^{13}$ This inversion of value is not surprising and fits within the framework of Christian beliefs, which is based on Christ's redeeming death, a death that was carried through a humiliating type of execution reserved to the lowliest criminals and yet became a foundational event for a religion, a moment to be celebrated and venerated, establishing a pattern in which violence to the martyr's body becomes a glorious event. ${ }^{14}$ This being said, even the etymological origin of our modern word, the Polynesian tatu or tatau, "to strike," while referring to the actual process, nevertheless contains an element of violence.

Noting that both graffiti and tattoos are indelible, I remarked upon the fact that the permanence of Arborio's inscriptions contributes to affirming the longevity of the town's history and existence. Another feature graffiti and tattoos share is that they both consist in the puncturing of a surface. Obviously, I am not talking here about modern graffiti made with aerosol cans or any other type of paint or writing material, but "real" graffiti, which are incised. The etymology of the word makes this clear: graffito is derived from the Italian sgraffiare, to scratch. It is interesting to note that in Japanese, one of the words for tattoo is horimono, literally, "engraved thing" (Poysden and Bratt 106). In so doing, both the frescoes' intonaco and the skin become a site for exchanges - a contact zone. In the case of graffiti on religious frescoes (a phenomenon more widespread than what has been so far acknowledged; see Plesch "Beyond Art History" 54), the incision becomes a way to "get in touch" with the depicted holy figures, while it also offers a trenchant translation of Erwin Panofsky's "kontemplative Versenkung," or contemplative immersion, the state the beholder aims to achieve in front of devotional images (264).

The JMEMS essay was the first time I considered parallels between graffiti and tattooing, but the readings I did on the subject of tattooing proved to be so fascinating that I ended up developing a seminar on The Visual Culture of Tattooing, which I have taught now twice and which has given me ample occasions to deepen my thinking about this practice. As I now shift all my attention to tattooing, I will use it as a terrain to reflect further upon issues of borders, of crossing borders, and of appropriation. Indeed the history of tattooing involves travel: tattooed bodies - of pilgrims, sailors, soldiers, convicts ${ }^{15}$ - moving and crossing borders, and the practice migrating across cultures and

13 See Gustafson 29-31 for examples of voluntary tattooing among early Christians. "And thus what had been a mark of crime and punishment, of degradation and subjection to earthly power was intentionally (or sometimes not so intentionally) transformed into a sign of glory and honour, of integrity, of holiness, of the victory of God's power" (Gustafson 31).

14 "La gloire_c'est-à-dire le sacrifice et le martyre: une manière de défiguration" (Didi-Huberman 130).

15 And also of "savages" captured and taken to Europe to be displayed as exotic curiosities (Oettermann 193-96), such as the Polynesian Omai, brought back by Captain Cook after his second circumnavigation (Guest). 
social classes, and in doing so, mutating in meaning. ${ }^{16}$ Although tattooing goes back to prehistory and was very likely practiced by many cultures in Antiquity (the problem is one of terminology: for instance, where the Ancient Picts painted or tattooed $?^{17}$ ), here are just two examples illustrating the nomadic quality of tattooing. The exoticism of the tattooed "savage" bodies that were "discovered" during Pacific exploration had an enormous impact on the European imaginaire and led to the Western appropriation of the practice in the $18^{\text {th }}$ century (Guest 100). Olive Oatman traveled between cultures: when she was fourteen, in 1851, her family was killed in today's Southern Arizona by Yavapai Indians, who captured her and a year later traded her to the Mohave. When four years later she returned to the white world, the blue tattoo on her chin caused a sensation. ${ }^{18}$ Margot Mifflin explains that this mark was "about crossing over culturally and becoming a Mohave" (qtd. in Stratford). As it turns out, the Mohave did not tattoo captives, but only their own people.

But, more importantly, tattooing is an affair of skin crossing: nobody expressed it better than Alfred Gell in his magisterial Wrapping in Images: Tattooing in Polynesia, published in 1993: "what tattooing reveals $[\ldots]$ is an inside which comes from the outside, which has been applied externally prior to being absorbed into the interior. The basic schema of tattooing is thus definable as the exteriorization of the interior which is simultaneously the interiorization of the exterior" (38-39). Gell was specifically referring to the Marquesan notion of being armored by tattoos but the ubiquity of his quote shows how it captures the essence of the practice: hardly any scholar writing on tattooing seems to be able to avoid citing it! An important source for the development of Gell's formulation is Didier Anzieu's psychoanalytical study of the skin, Le Moi-peau. Gell recognized that "the key to Anzieu's approach is contained in the insight into the doublesidedness of the skin, which both protects the 'primal cavity' of the body from the external world, yet at the same time reveals and communicates the internal state of this primal cavity to the external world" (Gell 29). The skin is both impermeable as it contains and protects and yet permeable as it is porous and allows exchanges; it is also superficial_-just think about the expression skin-deep - and yet has great depth (Anzieu 39). These are some of the many paradoxes that, according to Anzieu, characterize the skin. As the largest - and most external—of our organs, the skin reflects our health, while it is also, as Anzieu puts it, the "mirror of our soul" (39). Anzieu inventories the range of functions the skin fulfills: a containing "bag"; an interface that marks

16 See Caplan xv for the European "tattoo's unfixity" and its "nomadic" yet "contested status."

17 See, for instance, MacQuarrie.

18 Starting with a best-selling biography published shortly after her release, Oatman made public-speaking engagements for almost a decade, and countless works of literature and art. See Mifflin. 
a boundary acting as a barrier and yet also functions as a means of communication and a surface for inscriptions (61-62). Anzieu concludes that, whatever the function, the skin possesses a transitional status of intermediary, of in-between (39). It is remarkable that the skin both feels and touchesAnzieu talks of "bipolarité tactile" (107)-is aware of external conditions, heat and cold, and of course breathes, sweats, and absorbs. What Anzieu proposes is that the skin is constitutive of the ego-it is the ego. Freud had already anticipated that, when he declared "[ $t]$ he Ego is first and foremost a bodily ego; it is not merely a surface entity, but is itself the projection of a surface" (Freud 19; Anzieu 107). In this sense, the "envelope" Anzieu describes is like a border. The skin might appear to lack depth and similarly borders are mere lines on maps and yet, as our conference title makes it clear, they are not air-tight, they can be crossed - and the gerund in "Crossing" further emphasizes the dynamic nature of what takes place at borders. The exchanges that occur within the density of the skin have a double orientation-immigration and emigration, if you will!

In his work on the ego and on transitional states between wake and dream, Paul Federn, who for Anzieu is a "penseur des limites" (111), showed that limits act not as an obstacle or a barrier but rather as the condition that allows the psyche to establish distinctions - between, for instance, inside and outside, what is physical and what is not, or what comes from the Ego and from the others. Anzieu considers that Federn's formulation anticipates the physico-mathematical concept of interface. What is important for my argument is that, as René Thom has shown for mathematics, the "effets d'interface" allow for transformations - for a morphogenesis - to occur. And indeed, in the case of tattooing, as the skin is appropriated to receive a text (visual or verbal), exchanges take place in it and through it; this is Gell's "exteriorization of the interior which is simultaneously the interiorization of the exterior." And these exchanges, regardless of the tattoo's motivation and/or function, have an eminently transformational quality. Hence the role tattooing plays in many traditional societies as part of rites of passage. We owe to Arnold van Gennep the theorization of such rituals that occur at times of change and transition, and which are composed of three successive stages: a preliminary one, characterized by rites of separation; a transitional one in which the subject is suspended in a liminal state; and finally a postliminary stage in which rites of aggregation or incorporation take place. Van Gennep stressed the fact that limen is Latin for threshold and that separation rites often involve the actual passing of such an architectural feature and, more generally, of a physical movement (52).

When describing Polynesian tattooing, Gell perceived a scheme (what he called the "technical scheme of tattooing"), which, in its tripartite structure parallels that of rites of passage: first the piercing of the skin, then the insertion of pigment and at the same time bleeding, and finally the healing (9). 
You might have noticed that the central moment, corresponding to the liminal phase in van Gennep's rites of passage, is one in which exchanges take place, with the ink being inserted into the skin (to be precise, through the epidermis and into the dermis), while at the same time blood flows in the opposite direction. The tattoo, the trace left by the process, is as Gell stressed, an indelible mark (9) that operates a distinction, functioning, as Jane Caplan put it "as a marker of difference, an index of inclusion and exclusion" (xiv). In that sense, tattoos define boundaries. This is of course what happens in a tattoo acquired during a rite of passage, as it declares the wearer's new status, or, to be more precise, bears witness to the successful execution of a transformational ritual. Similarly, in the case of penal tattoos, the marks stigmatize the wearer for life, changing his/her status and identity. And this is why Olive Oatman's chin tattoo was so problematic as it continued affirming her Mohave identity long after she had been returned to the white world, leaving her with an "unresolved duality" in her hybrid identity (Mifflin 5). Tattoos also impact behavior and psychology: in Japan's Edo period, tattoos were sometimes called isamihada, or "courage skin" (Poysden and Bratt 125). Studying tattooing in the Later Roman empire, Mark Gustafson considered its psychological implications when used as a penal measure, explaining that

[e]xternally the tattooed person is subjectified, marginalized, degraded and stripped of selfesteem, reputation and standing in the community. But the subjection and discipline of the body is accompanied by the subjectification of the soul. The forcible imposition of the external mark, this disfigurement, serves to make a lasting impression internally" (24-25).

The transformative nature of tattooing endures today. Susan Benson notes how getting a tattoo still functions as a "rite of passage," and how that term is much used in what she calls "tattoo-talk" (245). The significant amount of tattoos acquired in response to trauma bears witness to the transformative potential of the practice. At a basic level, a tattoo can make up for the loss, for instance in the case of areolas and nipples tattooed in a trompe-l'oeil manner to complete reconstructive surgery after breast cancer. But when the missing part cannot be replaced by a pictorial ersatz, then the disfigured body can still be creatively appropriated. A Google search with the keywords "tattoo" and "amputation" reveals the extraordinary inventiveness that goes into those "body projects." 19 A stomp becomes a shark, its mouth opened to reveal a threatening set of sharp teeth (we might wonder if the loss of the arm was the result of a shark attack), or, more benignly, a dolphin, whose body extends from shoulder to shoulder. Tattoos covering mastectomy scarsand sometimes the absent breast - are growing in popularity and the benefits are such that some tattoo artists offer special rates to survivors (see, for instance, Kang and Jones 45-46) and the not-for-profit foundation P.ink (short for Personal Ink), whose motto affirms: "Breast Cancer Doesn't Have To Leave The Last Mark,"

19 For the notion of "body project," see Shilling. 
helps women in need pay for their tattoo and provides resources such as a gallery of tattoos, a directory of artists with experience in post-mastectomy tattoos, and even an iPhone app to try out designs (P.ink).

At times, the ways in which tattoos enter in a dialog with the missing or mutilated body part is not without a certain dose of humor. This is particularly true for textual tattoos acquired as a way of appropriating the results of amputation. For instance, a hand, which fingers have been lost, carry the words "No Room for Hate" while the healthy one bears "LOVE" tattooed on the knuckles; "shark attack" and "frost bite" are written with an arrow pointing to missing toes; "Out of order" is right over a mutilated ear; and "Some assembly required" is on a stomp, right where the prosthetic leg is to be affixed. In some cases, it is the healthy leg that bears the tattoo and as a result establishes a dialog with the prosthetic one, declaring: "one foot in the grave," or, accompanied by a finger pointing to the other, missing leg: "I'm with stumpy." One might wonder if the tattooed text doesn't act as a surplus, one that compensates for the loss, just like names on memorials and tombstones stand for the departed. As the tattooed text engages in a dialog with the missing body part, by acknowledging it, it makes it present again. And what is exactly the function of humor? Certainly, as countless authors have affirmed it, one is better off laughing than crying about something..$^{20}$ As we know, humor itself possesses transformative qualities and has been recognized as enhancing health, psychological well-being, and resiliency.

Tattoos can also interact with - indeed appropriate and transform — scars, and thus contribute to reclaiming a blemished body. Verbal tattoos, in particular, when placed over scars literally rewrite the trauma, acting as an affirmation of agency, of control over a body that has been threatened. In all its embodiments and regardless of cultural and historical context and of purpose, the practice of tattooing squarely fits within what Kathy and I suggested about the processes of cultural appropriation for it is always aimed at affirming power and consolidating identity. One of my students, reflecting upon acquiring her own tattoo, explained: "I felt an overwhelming sense of agency in choosing the time and the manner in which I received my body art-as many people do." This is why tattooing is so frequently practiced in prisons as the body is the inmates' only possession. ${ }^{21}$

20 For instance Beaumarchais: “Je me presse de rire de tout, de peur d'être obligé d'en pleurer" (65; act I, scene 2) and Rabelais: "Mieux est de ris que de larmes escripre" (2).

21 Juliet Fleming writes: "Tattooing in prison is felt to be an affirmation that (at least) this body is yours" (63). 
In the context of word and image studies, I find tattoos with inspirational sentences particularly fascinating. ${ }^{22}$ The wrist, as it is easily accessed for viewing, seems to be a favorite site for such statements meant to guide the wearer (Fig. 9). I am reminded of Claire Richter Sherman's exhibition and book on Writing on Hands: Memory and Knowledge in Early Modern Europe in which she considered the hand as "a meeting place for matter, mind, and spirit." ${ }^{23}$ And indeed, because hands establish a direct relationship with the brain, they assist our cognitive functioning in many ways (Fig. 10). For tattoos, placement is, as tattoo artist Maxime Büchi declares, "crucial. Placement and size is everything. The same design at a different place and scale is a different tattoo" ("Maxime Büchi"). In other words, the location is part of a tattoo's message. We could also say that tattoos are palimpsests, as they appropriate a pre-existing surface, which primary function is not to hold that particular text (visual

22 The frequency with which some of these verbal tattoos reproduce the handwriting of family members, particularly deceased ones, is remarkable.

23 Book's summary.
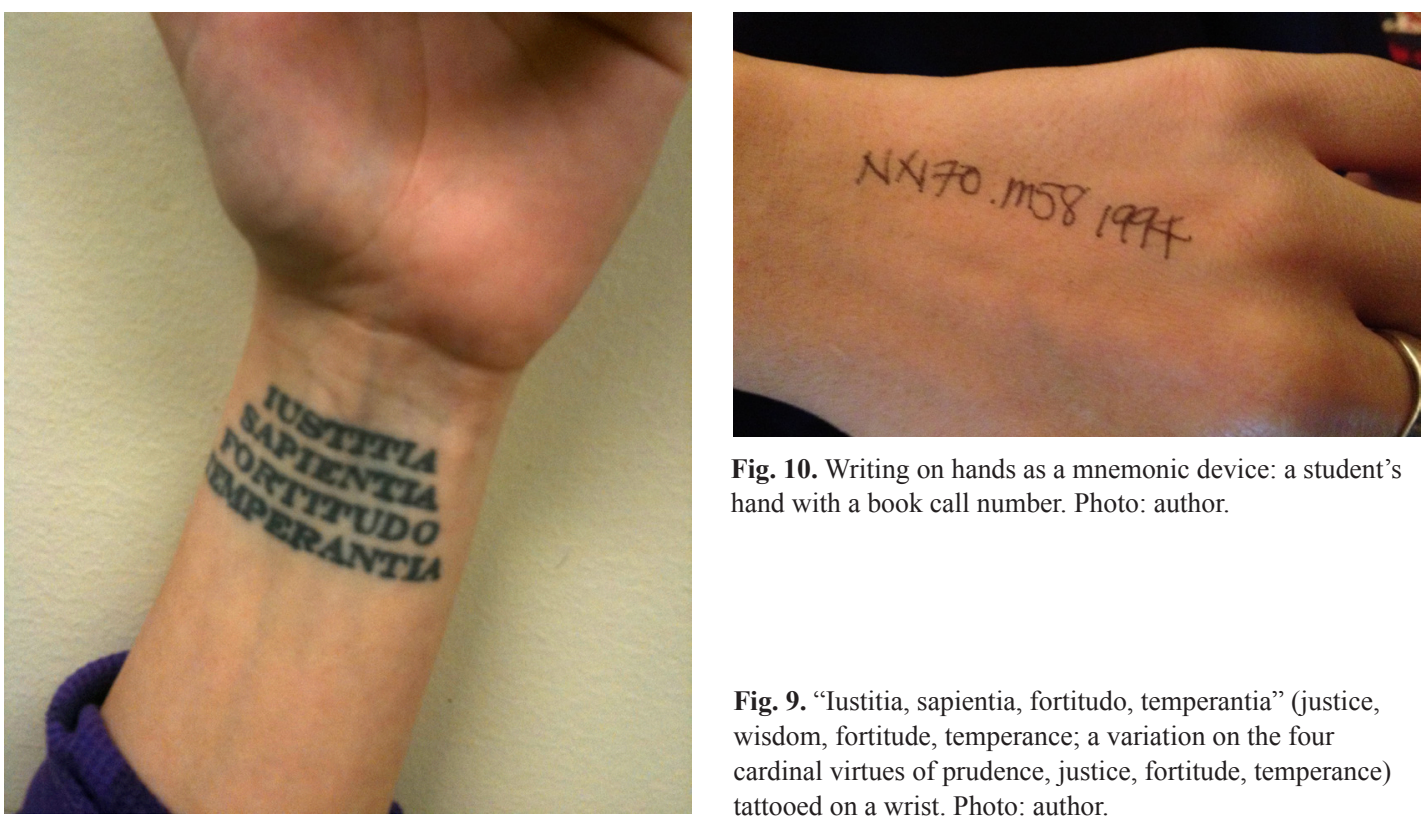

Fig. 10. Writing on hands as a mnemonic device: a student's hand with a book call number. Photo: author.

Fig. 9. "Iustitia, sapientia, fortitudo, temperantia" (justice, wisdom, fortitude, temperance; a variation on the four cardinal virtues of prudence, justice, fortitude, temperance) tattooed on a wrist. Photo: author. 
or verbal). What the notion of palimpsest adds to our discussion is how in it the two axes of space and time converge: palimpsests are objects - a site - upon which a certain type of layering has occurred over a period of time.

\section{Hic et Nunc-Place and Time}

Invariably, when I talk about tattoos, people ask me if I have one-yes, I do: so far only one. Even though discoursing on a mark on my skin might seem a bit self-indulgent, this allows me to address the two axes of space and time, and circle back to the notion of appropriation. The phrase I chose for my tattoo, "hic et nunc," is one I realized I was often using in my scholarship, especially when dealing with anachronistic details in late medieval Christian art. So yes, these are words that say something about my intellectual identity, but they also struck me as being a great motto to live by, quite Zen come to think about it, a wonderful reminder worth having written on one's body. "Here and Now": Space and Time. On my lower back, the three words form a horizontal line that corresponds to the axis of the pelvis and are placed at the very base of the vertical one of the spine (and therefore can be seen as symbolically giving it grounding), while the articulation between the two words, the "and" summarized by an ampersand, corresponds to the anatomical articulation of the spine. So by appropriating this Latin phrase, I said something about my scholarship, about how I understand the uses of anachronism in the works I study, but also by appropriating the surface of my body, I am saying something to me, and working on myself. This affirmation of the present moment in the lasting medium of tattooing operates as a temporal border, separating past from present and from future. Scholars point out the paradox of how a tattoo is a permanent mark (sure, it can be removed but it is not easy nor cheap!) and how, because it is "forever" on the body, it points to the finite nature of its support: it is there until you die.

A tattoo marks a moment in time: I remember very clearly the circumstances in which I got mine on 2 July 201_and this, by the way, is true of scars. Very often, when describing their ink, people mention the exact moment they were made:

I got this tattoo July $17^{\text {th }} 2010$ at the Illustrated Man in Camp Hill, PA. This tattoo is the first one I had done and I continue to love this as my life motto. The phrase 'I will make better mistakes tomorrow' is not an excuse for my actions, it's a truce to myself that no matter what, I will always make mistakes. However, I will always learn from them and therefore, make a better mistake tomorrow. It's a reminder to never be too hard on myself." 24

24 The tattoo along with the accompanying was originally posted on 7 May 2012 on Tumblr on FYEAHTATTOOS. COM (http://fyeahtattoos.com/); it is now visible at: http://citycritik.tumblr.com/post/22586052958/ fuckyeahtattoos-i-got-this-tattoo-july-17th. 
Notice the future tense in the tattooed text and how the owner talks about her ink. I would argue that it is because tattoos mark a moment in time that they make a projection into the future possible. In her article "Tattoo Narratives: The Intersection of the Body, Self-Identity and Society," Mary Kosut, who considers that tattoos are a form of "biographical documentation," quotes a young woman who describes the power she feels getting a tattoo, adding that "each time I have gotten one done [...] it's been some kind of landmark for myself [...] of starting another time in my life." (94) Another interviewee explains that his tattoo is "an actual bookmark of one chapter closing and one chapter opening." (94) You will notice that as they mark a moment a time, these tattoos articulate time, and establish a boundary between past and future-I will come back to this.

We might be reminded of Foucault's famous statement that "the body is the inscribed surface of events" (148), but the difference from the scars and blemishes our body acquires as we live (and the more metaphorical ones that are imposed by society and power structures ${ }^{25}$ ), is that tattooing is chosen -well, not always. Here is what Primo Levi wrote about the tattoo he received as a concentration camp inmate:

My number is 174517 ; we have been baptized, we will carry the tattoo on our left arm until we die.

The operation was slightly painful and extraordinarily rapid: they placed us all in a row, and one by one, according to the alphabetical order of our names, we filed past a skilful official, armed with a sort of pointed tool with a very short needle. It seems that this is the real, true initiation: only by 'showing one's number' can one get bread and soup. [...] And for many days, while the habits of freedom still led me to look for the time on my wristwatch, my new name ironically appeared instead, its numbers tattooed in bluish characters under the skin (27-28).

It is when he would want to consult the time that Levi would see the tattoo and this sight would assert his presence at Auschwitz, a place where, as Rob Baum put it, "even time has been removed, replaced with endless torture" (124).

The abjection represented by tattooing at Auschwitz-Birkenau (which, by the way, were the only camps where this was done) is profoundly emblematic of the Shoah, of a process of dehumanization in which individuals became mere numbers, with the marking affirming property by the state, and, to

25 Of course, a perfect illustration is to be found in Kafka's In The Penal Colony. 
add insult to injury, transgressing the Jewish belief that tattooing is forbidden (See Leviticus XIV, 28 and Deutoronomy XIX, 10). There is no scriptural basis for the view, prevalent in some quarters of the US, that you cannot be buried in a Jewish cemetery if you have a tattoo (Lucas). To complicate the issue further, it should be noted that concentration camp tattoos can acquire for some a positive meaning as they become proof of resiliency and survival - but this of course only later, after the fact. ${ }^{26}$ Which leads me to saying a few words of the recent — and quite unsettling - trend among young Jews to tattoo on their arm their grandparents' concentration camp numbers. I believe we should frame this instance of appropriation in the context of what has been called "second-generation memoirs." But since this involves not the children of survivors, but their grandchildren, these tattoos are instead acting as a "thirdgeneration memoir." The issue at stake is that the original generation is fast disappearing, so the question is: who will bear witness so we shall "never forget"? I am reminded of what Judith Holland Sarnecki wrote about tattooing as a "creative mourning [that] leads away from melancholia and toward survival by marking the absence and filling the void" (36-37). It is important that this memoir of sorts is written on the body as this is what disappears when someone dies. The dual function of memoirs - for the self and to educate others - parallels the double orientation of tattooing (and of the skin and of borders).

One aspect of tattoos that I have not yet mentioned and that is extremely important (and particularly relevant to our word and image context) is that they have a "distinctive narrative quality" (Kosut 85). Better still, they make the wearer tell a story that addresses all the usual questions: why, what, where (and of course, who). In an article published in The New York Times in 2012, a young man, photographed posing with his grandmother, explained the reason for his concentration camp tattoo: "all my generation knows nothing about the Holocaust [...]. You talk with people and they think it's like the Exodus from Egypt, ancient history. I decided to do it to remind my generation: I want to tell them my grandmother's story and the Holocaust story" (qtd. in Rudoren). These grandchildren are bearing witness but they are also still working through trauma. Cathy Caruth defines trauma as "the response to an unexpected or overwhelming violent event or events that are not fully grasped as they occur, but return later in repeated flashbacks, nightmares, and other repetitive phenomena" (91). What Freud called "traumatic neurosis" and what we now refer to as post-traumatic stress syndrome, should be understood as attempts at grasping the traumatic event. What is important for my argument, is that, as Caruth explains, trauma "is in fact a break in the mind's experience of time" (61), and so the flashbacks keep one literally stuck in the past. The healing process entails facing the trauma as well as recognizing that it took place in the past, for only then can one start addressing the future.

26 Primo Levi mentions that already at Auschwitz, inmates bearing numbers 30,000 to 80,000 were treated "with respect" as they "represented the few survivals from the Polish Ghettos" (28). 
Inscribed in the border zone of the skin, tattoos articulate the boundaries among past, present, and future. The present moment in which the tattoo is made becomes a precise moment in the past - one that, as we have seen, is never forgotten (the pain involved probably plays a role here). The inscription - whether verbal or visual - will be there forever; a message to oneself and to the outside world to be read in the future, or rather, at a present moment in the future. The skin, our personal border that protects and reveals, that mediates between our inside and the outside, is a palimpsest displaying marks -voluntary or not - that represent moments in time. I am reminded of a scene in David Cronenberg's Eastern Promises, in which the character played by Viggo Mortensen faces, almost completely naked, a panel of men, who are in effect "reading" the visual resume that his Russian prison tattoos constitute, as they are indeed highly codified (Lambert and Christ).

Another movie, Peter Burger's The Tattooist, will allow me to recapitulate some of the issues I have discussed in this essay. The main character, Jake Sawyer, is an American tattoo artist who sports a collection of tattoos that record all the different places he has visited in his globe-trotting career. His "shtick" is to pretend that his work has healing properties but it is made quite clear that he does not believe in them, and so in that sense, both in his body and in his business, Jake is a perfect illustration of cultural appropriation in the negative sense it often has today, one in which the original meaning is almost completely lost. The movie opens up on what turns out to be a flashback, a moment of intense trauma in Jake's past, when his religious father forcibly removes a tattoo from his left forearm. By erasing a mark that the young Jake, in an affirmation of agency, had chosen, the father reclaims his son's body and the scar he leaves affirms his ownership. After this stigmatizing inscription of the father's power (later in the movie we learn that in Samoan culture tattoo designs are handed down from father to son), we switch to the present time, to the adult Jake and his now heavily tattooed body. In the next scene, we see two worlds colliding: Jake is naked, sporting his "primitive" tattoos, and is juxtaposed to the backdrop of a modern city, which, it turns out, is a foreign one (he is in Singapore). The film is filled with allusion to boundaries and to their transgression. Jake steals a Samoan tattooing tool and after he accidentally punctures his skin with it, he dreams of tattooing and sees ink penetrating the skin and blood coming out-visual translations of Gell's famous statement that will recur throughout the movie. And then, as he carries on his trade, the tattoos he gives, although made with a modern tattoo gun, take on a life of their own and eventually kill the customers. The movie is also replete with binary oppositions, between modern and "primitive," Europeans and non-Europeans, and more specifically between Westerners and Samoans, but also between the living and the dead, and even between rational 
consciousness and irrational unconscious (revealingly so, the tattoo parlor in Auckland, New Zealand, where Jake takes up residence, is called Bedlam). Of course, these binaries are not separated by air-tight borders, as is shown by the puncturing of Jake's skin with the stolen tool that opens up a portal to the spirit world. Boundaries and exclusion are also featured prominently: the Samoans call Jake "outsider" and the evil sprit that Jake accidentally unleashes is the result of shame. We learn that the worst thing Samoans can do is to bring shame to their family and we see the results with a family ostracized by its community, living in humiliating squalor. ${ }^{27}$ There is a love story and there is a happy ending. Sina, the Samoan woman Jake has fallen in love with but almost killed by tattooing her, is saved in extremis and the scars left by the evil spirit are incorporated into a beautiful tattoo, while the shamed family is welcomed back again into its community. There is no need to recapitulate the exact details of how the malevolent spirit is finally subdued, but suffice to say that here too, tattoos are involved - along with father-and-son-relations. In last analysis, it is on the skin that the tale told by this movie truly enfolds: as Enid Schildkrout put it, "the body, as a canvas, is not only the site where culture is inscribed, but also a place where the individual is defined and inserted into the cultural landscape" (338).

27 In a trenchant social commentary, we see young Samoans living in urban settings pretty much like American inner city minorities, and we realize that the original inhabitants have been pushed to the margins of society. 


\section{Works Cited}

ANZALDÚA, Gloria. Borderlands/La Frontera: The New Mestiza. San Francisco: Spinsters/Aunt Lute, 1987.

ANZIEU, Didier. Le Moi-peau. 1985. Revised edition Paris: Dunod, 2006.

ASHLEY, Kathleen and Véronique PLESCH, eds. The Cultural Processes of "Appropriation." Special issue of the Journal of Medieval and Early Modern Studies 32.1 (2002).

BAL, Mieke. Travelling Concepts in the Humanities: A Rough Guide. Toronto, Canada: University of Toronto Press, 2002.

BARTHES, Roland. "The Death of the Author.” 1968. Image-Music-Text. Trans. Stephen Heath. New York: Hill and Wang, 1977. 142-48.

BAUM, Rob. "And Thou Shalt Bind Them as a Sign upon Thy Hand: Eve's Tattoo and the Holocaust Consumer." Shofar 28. 2 (2010): 116-38.

BEAUMARCHAIS (Pierre Augustin Caron de). Le Barbier de Séville. Ed. Georges Bonneville. Paris: Bordas, 1963.

BELL, Catherine. Ritual Theory, Ritual Practice. Oxford University Press, New York and Oxford: Oxford University Press, 1992.

BENSON, Susan. "Inscriptions on the Self: Reflections on Tattooing and Piercing in Contemporary EuroAmerica." Written on the Body. The Tattoo in European and American History. Ed. Jane Caplan. Princeton: Princeton University Press, 2000. 234-54.

BHABHA, Homi K. The Location of Culture. New York: Routledge, 1994.

BLOOM, Harold. Anxiety of Influence: A Theory of Poetry. New York: Oxford University Press, 1973.

BOURDIEU, Pierre. Distinction: A Social Critique of the Judgment of Taste, trans. Richard Nice. Cambridge: Harvard University Press, 1984.

BURGER, Peter. The Tattooist. Screenplay by Matthew Grainger and Jonathan King. Buena Vista International, Ghost House Underground, and Sony Pictures Entertainment, 2007.

CAPLAN, Jane, ed. Written on the Body. The Tattoo in European and American History. Princeton: Princeton University Press, 2000.

CARUTH, Cathy. Unclaimed Experience: Trauma, Narrative and History. Baltimore: The Johns Hopkins University Press, 1996.

CASTELNUOVO, Enrico. "Les Alpes, carrefour et lieu de rencontre des tendances artistiques au XVe siècle." Études de Lettres 10.1 (1967): 13-26.

. "Les Alpes au début du XVe siècle: une Kunstlandschaft?" Historische LandschaftKunstlandschaft? Der Oberrhein im späten Mittelalter. Ed. Peter Kurmann and Thomas Zotz. Ostfildern: Jan Thorbecke. 2008. 19-30.

CASTELNUOVO, Enrico and Carlo GINZBURG, "Centro e periferia." Storia dell'arte italiana, Parte prima: Materiali e problemi, Volume primo: Questioni e metodo. Milan: Einaudi, 1979. 285-352.

CRONENBERG, David, dir. Eastern Promises. Screenplay by Steven Knight. Focus Features, 2007.

DIDI-HUBERMAN, Georges. "Un sang d'images," Nouvelle Revue de Psychanalyse 32 (1985): 123-53.

FLEMING, Juliet. "The Renaissance Tattoo." Written on the Body. The Tattoo in European and American History. Ed. Jane Caplan. Princeton: Princeton University Press, 2000. 61-82. 
FOUCAULT, Michel. "Nietzsche, Genealogy, History." 1971. Language, Counter-Memory, Practice: Selected Essays and Interviews. Ed. Donald F. Bouchard, trans. Donald F. Bouchard and Sherry Simon. Ithaca: Cornell University Press, 1977. 139-164.

FREUD, Sigmund. The Ego and the Id. Trans. Joan Riviere, ed. James Strachey. New York: W.W. Norton and Company, 1960.

GELL, Alfred. Wrapping in Images: Tattooing in Polynesia, Oxford: Clarendon Press, 1993.

GUEST, Harriet. "Curiously Marked: Tattooing and Gender Difference in Eighteenth-century British Perceptions of the South Pacific. Written on the Body. The Tattoo in European and American History. Ed. Jane Caplan. Princeton: Princeton University Press, 2000. 83-101.

GUICHONNET, Paul, ed. Histoire et civilisations des Alpes. I, Destin historique. Toulouse: Privat; Lausanne: Payot, 1980 .

GUSTAFSON, Mark. "The Tattoo in the Later Roman Empire and Beyond." Written on the Body. The Tattoo in European and American History. Ed. Jane Caplan. Princeton: Princeton University Press, 2000. 17-31.

KAFKA, Franz. "In the Penal Colony." The Complete Stories. Ed. Nahum Glatzer. New York: Schocken, 1971. 140-67.

KANG, Miliann and Katherine JONES. "Why do People get Tattoos?” Contexts 6 (2007): $42-47$.

KLUCKHOHN, Clyde. "Myths and Rituals: A General Theory," Harvard_Theological Review 35 (1942): 45-70.

KORENY, Fritz. "Israhel van Meckenem.” Print Quarterly 18.4 (2001): 469-72.

KOSUT, Mary. "Tattoo Narratives: The Intersection of the Body, Self-Identity and Society." Visual Sociology 15 (2000): 79-100.

LAMBERT, Alix and Mary CHRIST. Russian Prison Tattoos: Codes of Authority, Domination, and Struggle. Atglen: Schiffer, 2003.

LEVI, Primo. Survival in Auschwitz: The Nazi Assault on Humanity. Trans. Stuart Woolf. New York: Touchstone, 1996.

LUCAS, Rabbi Alan B. "Tattooing and Body Piercing.” 1997. https:/www.rabbinicalassembly.org/sites/default/ files/public/halakhah/teshuvot/19912000/lucas tattooing.pdf

MACQUARRIE, Charles W. "Insular Celtic Tattooing: History, Myth and Metaphor." Written on the Body. The Tattoo in European and American History. Ed. Jane Caplan. Princeton: Princeton University Press, 2000. 32-45.

"MAXIME BÜCHI." Inked (8 February 2016). http://www.inkedmag.com/artists/maxime-buchi/

MIFFLIN, Margot. The Blue Tattoo: The Life of Olive Oatman. University of Nebraska Press, 2009.

NELSON, Robert S., "Appropriation." Critical Terms for Art History. Ed. Nelson Robert S. and Richard Shiff. Chicago: University of Chicago Press, 1996. 160-73.

NELSON Robert S., and Richard SHIFF, eds. Critical Terms for Art History. Chicago: University of Chicago Press, 1996.

OETTERMANN, Stephan. "On Display: Tattooed Entertainers in America and Germany." Written on the Body. The Tattoo in European and American History. Ed. Jane Caplan. Princeton: Princeton University Press, 2000. 193-211.

PANOFSKY, Erwin. "Imago Pietatis: ein Beitrag zur Typengeschichte des 'Schmerzensmannes' und der 'Maria Mediatrix.'” Festschrift für Max J. Friedländer zum 60. Geburstag. Leipzig: E. A. Seeman, 1927. $261-308$.

PARRY, Benita. "Problems in Current Theories of Colonial Discourse" Oxford Literary Review 9 (1987): $27-58$. 
P.INK. http://p-ink.org/

PLESCH, Véronique. "Le Couronnement de la Vierge de Waltensburg. Un problème iconographique de l'art grison au XVe siècle." Nos monuments d'art et d'histoire 3 (1985): 345-50.

. "Innovazione iconografica e unità alpina: la Vergine incoronata dalla Trinità." Lo spazio alpino: area di civiltà, regione cerniera. Ed. G. Coppola and P. Schiera. Quaderni di Europa Mediterranea, 5. Naples: Gisem/Liguori Editore, 1991. 263-79.

."Enguerrand Quarton's Coronation of the Virgin: This World and the Next, the Dogma and the Devotion, the Individual and the Community." Historical Reflections / Réflexions Historiques 26. 2, The Last Things (2000): 189-221.

. "Memory on the Wall: Graffiti on Religious Wall Paintings." The Cultural Processes of Appropriation. Ed. Kathleen Ashley and Véronique Plesch, special issue of the Journal of Medieval and Early Modern Studies 32.1 (2002): 167-97.

. "L'Art du XVe siècle dans les Alpes: au nord ou au sud?" Frontières, contacts, échanges. Mélanges offerts à André Palluel-Guillard. Ed. Christian Sorrel. Chambéry: Société Savoisienne d'Histoire et d'Archéologie and Université de Savoie, 2002. 69-82.

Painter and Priest: Giovanni Canavesio's Visual Rhetoric and the Passion Cycle at La Brigue. Notre Dame: University of Notre Dame Press, 2006.

. "Beyond Art History: Graffiti on Frescoes." In Understanding Graffiti. Ed. Troy Lovata and Elizabeth Olton. Walnut Creek: Left Coast Press, 2015. 45-57.

POYSDEN, Mark, and Marco BRATT. A History of Japanese Body Suit Tattooing. Amsterdam: KIT, 2006.

PRATT, Marie-Louise. Under Imperial Eyes: Travel Writing and Transculturation. New York: Routledge, 1992.

RABELAIS, François. La Vie très horrificque du grand Gargantua, père de Pantagruel. Oeuvres complètes. Ed. Jacques Boulanger and Lucien Scheler. Paris: Gallimard, 1935.

RENZA, Louis A. "Influence." Critical Terms for Literary Study. Ed. Frank Lentricchia and Thomas McLaughlin. 2nd ed. Chicago: University of Chicago Press, 1995. 186-202.

RUBIN, Arnold. "The Tattoo Renaissance." Marks of Civilization: Artistic Transformations of the Human Body. Ed. Arnold Rubin. Los Angeles: Museum of Cultural History, University of California, Los Angeles, 1988. 233-62.

RUDOREN, Jodi. "Proudly Bearing Elders' Scars, Their Skin Says 'Never Forget."” The New York Times. (30 September 2012). http://www.nytimes.com/2012/10/01/world/middleeast/with-tattoos-young-israelisbear-holocaust-scars-of-relatives.html?pagewanted=all

SARNECKI, Judith Holland. "Trauma and Tattoo." Anthropology of Consciousness 12.2 (2001): 35-42.

SHERMAN, Claire Richter. Writing on Hands: Memory and Knowledge in Early Modern Europe. Carlisle, Pa.: Trout Gallery, Dickinson College, 2000.

Shestack, Alan. Fifteenth Century Engravings of Northern Europe from the National Gallery of Art, Washington, D.C. Washington, D.C.: National Gallery of Art, 1967.

SHIFF, Richard. "Originality." Critical Terms for Art History. Ed. Nelson Robert S. and Richard Shiff. $2^{\text {nd }}$ ed. Chicago: University of Chicago Press, 1996. 145-59.

SHILling, Chris. The Body and Social Theory. London: Sage, 1993. 
SPONSLER, Claire. "In Transit: Theorizing Cultural Appropriation in Medieval Europe." The Cultural Processes of Appropriation. Ed. Kathleen Ashley and Véronique Plesch, special issue of the Journal of Medieval and Early Modern Studies 32.1 (2002): 17-39.

STRATFORD, Michael. “An English Professor Explores the Meaning of a $19^{\text {th }}$-Century Chin Tattoo.” Interview with Margot Mifflin. Chronicle of Higher Education 58.20 (January 20, 2012).

THE HARRIS POLL. "Tattoo Takeover: Three in Ten Americans Have Tattoos, and Most Don't Stop at Just One.” (10 February 2016). http://www.theharrispoll.com/health-and-life/Tattoo_Takeover.html

THÉREL, Marie-Louise. À l'origine du décor du portail occidental de Notre-Dame de Senlis: le triomphe de la Vierge-Eglise; sources historiques, littéraires et iconographiques. Paris: Éditions du C.N.R.S, 1984.

VAN GENNEP, Arnold. The Rites of Passage. 1909. Trans. Monika B. Vizedom and Gabrielle L. Caffee. London: Routledge \& Kegan Paul, 1960.

VERDIER, Philippe. Le couronnement de la Vierge. Les origines et les premiers développements d'un thème iconographique. Montreal: Institut d'études médiévales Albert-le-Grand, and Paris: Vrin, 1980. 


\section{LiST OF ILLUSTRATIONS}

Fig. 1. Enguerrand Quarton, Coronation of the Virgin, 1353-54. Tempera on panel. Musée de l'Hospice, Villeneuve-lès-Avignon.

Fig. 2. An early example of the iconography of the Virgin Crowned by the Trinity: anonymous Tyrolean artist, first quarter of the $15^{\text {th }}$ century. Tempera and oil on panel, Museum of Fine Arts, Boston.

Fig. 3. Coronation of the Virgin. Paris, $13^{\text {th }}$ century. Polychrome ivory. Musée du Louvre, Paris.

Fig. 4. Example of the type of Trinity that played a role in the creation of the iconography of the Virgin Crowned by the Trinity: illumination from a French Psalter, $3^{\text {rd }}$ quarter of the 13th century. MS. Douce 50, fol. 368r. Bodleian Library, Oxford.

Fig. 5 Giovanni Canavesio, Crowning with Thorns, 1492. Fresco. Notre Dame des Fontaines, La Brigue. Photo: author.

Fig. 6. Israhel van Meckenem, Israhel van Meckenem, Crowning with thorns, from the Large Passion series, c. 1480. Engraving. National Gallery of Art, Washington, DC.

Fig. 7. Saint Fabian and Saint Sebastian. Fresco. Oratorio di San Sebastiano, Arborio. Photo: author.

Fig. 8. Oratorio di San Sebastiano, Arborio, detail of graffiti on St. Sebastian: "1661 ali 17 genaro si e seminato dela avena a fato bono pro to G. Giletta" ("1661 on 17 January we sowed oats and made good pro t, G. Giletta"); "1654 [a otto] il mese di giuno la sesia a menato via il castello" ("1654 on 8 June the Sesia River took away the castle"); "1664 ali 30 marzo è venuto la neve alta un piede" ("1664 on 30 March a foot of snow fell"). Photo: author.

Fig. 9. "Iustitia, sapientia, fortitudo, temperantia" (justice, wisdom, fortitude, temperance; a variation on the four cardinal virtues of prudence, justice, fortitude, temperance) tattooed on a wrist. Photo: author.

Fig. 10. Writing on hands as a mnemonic device: a student's hand with a book call number. Photo: author. 